OPEN ACCESS

Edited by:

Jun Lu,

Auckland University of Technology,

New Zealand

Reviewed by:

Yan Li,

Auckland University of Technology,

New Zealand

Reza Nemati,

Auckland University of Technology,

New Zealand

Guozheng Huang,

Xinjiang Technical Institute of Physics

\& Chemistry (CAS), China

${ }^{*}$ Correspondence:

Akio Sakamoto

akiosaka@kuhp.kyoto-u.ac.jp

Specialty section:

This article was submitted to Nutrition and Food Science Technology,

a section of the journal

Frontiers in Nutrition

Received: 08 September 2017 Accepted: 20 December 2017 Published: 22 January 2018

Citation:

Hori Y, Sakamoto A, Goto T, Ando S, Yamashita M, Shimomura $M$ and Uemura T (2018) Analysis of Dietary Intake during Consecutive-Day Chemotherapy for Bone and Soft-Tissue Sarcomas.

Front. Nutr. 4:70.

doi: 10.3389/fnut.2017.00070

\section{Analysis of Dietary Intake during Consecutive-Day Chemotherapy for Bone and Soft-Tissue Sarcomas}

\author{
Yuta Hori',2, Akio Sakamoto ${ }^{3 *}$, Takashi Goto', Syouji Ando", Manato Yamashita', \\ Masayo Shimomura ${ }^{5}$ and Takuji Uemura ${ }^{6}$
}

\begin{abstract}
'Department of Pharmacy, National Hospital Organization, Kokura Medical Center, Kitakyushu, Japan, ${ }^{2}$ Department of Clinical Research Institute, National Hospital Organization, Kokura Medical Center, Kitakyushu, Japan, ${ }^{3}$ Department of Orthopaedic Surgery, Graduate School of Medicine, Kyoto University, Kyoto, Japan, ${ }^{4}$ Department of Nutrition Management, National Hospital Organization, Kokura Medical Center, Kitakyushu, Japan, ${ }^{5}$ Department of Pharmacy, National Hospital Organization, Oita Medical Center, Oita, Japan, ${ }^{6}$ Department of Pharmacy, Social Insurance Nakabaru Hospital,

Fukuoka, Japan
\end{abstract}

Background: Bone and soft tissue sarcomas are commonly treated with consecutive-day chemotherapy regimens consisting of multiple anticancer agents. Chemotherapyinduced nausea and vomiting (CINV) is a serious adverse effect of these regimens and may result in decreased energy intake during chemotherapy. Decreased energy intake may lead to undernutrition and may cause adverse effects on patient quality of life and survival.

Methods: Patients with bone and soft tissue sarcomas who received consecutive-day chemotherapy were retrospectively evaluated. CINV and dietary energy intake were assessed, as well as the occurrences of hiccups and constipation during chemotherapy.

Results: A total of 13 patients, 10 males and 3 females, with a total 16 chemotherapy courses were included in the study. All patients received antiemetic prophylaxis. The CINV control rate, defined as no emesis and no rescue therapy, gradually decreased from chemotherapy day 1 (94\%) to day 5 (75\%). Four patients experienced emesis, two of whom had been treated with a cisplatin-containing regimen. Decreased dietary energy intake was possibly associated with CINV during chemotherapy. Anorexia was grade 2 except for one case of grade 3 . The incidences of hiccups and constipation were high on days $3-5$.

Conclusion: Antiemetic prophylaxis treatment did not prevent emesis due to consecutive-day chemotherapy, especially with cisplatin-containing regimens, in patients with bone and soft-tissue tumors. Dietary energy intake decreased during chemotherapy, and this appeared to be associated with CINV. In addition, the incidence of hiccups and constipation increased during the course of consecutive-day chemotherapy regimens. Although these results are based on a small number of patients, it may be important to observe nutritional status during chemotherapy, as this may reflect a patient's general condition. Nutritional counseling might be useful in supporting nutritional status in patients undergoing chemotherapy.

\footnotetext{
Keywords: chemotherapy, nausea and vomiting, dietary, antiemetic, bone, soft-tissue, sarcoma
} 


\section{INTRODUCTION}

Chemotherapy-induced nausea and vomiting (CINV) is a nonhematologic toxicity associated with chemotherapy for malignant tumors (1). CINV is a collective term used to describe nausea, vomiting, or a combination of both symptoms, associated with chemotherapy. Although nausea and vomiting are related, they have distinct physiologic mechanisms $(2,3)$. Nausea is a subjective sensation of discomfort, typically associated with the epigastrium, which might result in vomiting. Because of its subjective nature, the sensation, location, duration, and intensity of nausea can vary $(4,5)$. CINV reduces patient quality of life and decreases treatment compliance. The degree of CINV is categorized by CINV frequency and is associated with the type, dose, and administration route of anticancer agents: low emetogenic risk, moderate emetogenic risk, and high emetogenic risk. Guidelines for the management of CINV recommend using a combination of dexamethasone and $5-\mathrm{HT}_{3}$ receptor antagonists with or without Neurokinin 1 (NK1) receptor antagonists as antiemetic prophylaxis for moderate emetogenic risk chemotherapy regimens. Triple antiemetic prophylaxis including dexamethasone, $5-\mathrm{HT}_{3}$ receptor antagonists, and NK1 receptor antagonists is recommended for high emetogenic risk chemotherapy regimens $(3,6)$.

Subclassification of CINV includes acute and delayed CINV. Acute CINV is generally considered to be nausea and/or vomiting that occurs within $24 \mathrm{~h}$ of chemotherapy administration. Delayed CINV is defined as nausea and/or vomiting that occurs after the first $24 \mathrm{~h}$ of chemotherapy administration $(4,7,8)$. Different physiological mechanisms have been suggested to cause acute versus delayed CINV (9). The risk of acute or delayed CINV depends partly on the emetogenic potential of the anticancer agents (10). In consecutive-day regimens involving multiple anticancer agents, the risk of acute CINV overlaps with the risk of delayed CINV due to multiple days of therapy. Therefore, CINV may be persistent in patients receiving consecutive-day regimens involving multiple anticancer agents (11).

Soft tissue sarcomas are malignant tumors located in any of the mesodermal tissues of the extremities, trunk, retroperitoneum, or head and neck, and include more than 50 histologic subtypes (12). Cytotoxic chemotherapy using anticancer agents is the mainstay of treatment for advanced soft tissue sarcomas (13). The cytotoxic agents used to treat soft tissue sarcomas can be associated with significant adverse events, including pancytopenia, febrile neutropenia, nausea, alopecia, and fatigue (12). Consecutive-day chemotherapy regimens involving multiple anticancer agents are widely used to treat bone and soft tissue sarcomas (11). In many regimens, high doses of anticancer agents are administered and are thus frequently associated with CINV (11). In most cases, anthracyclines alone, such as doxorubicin (DXR), or in combination with other agents such as ifosfamide, are first-line treatment for advanced soft tissue sarcomas (12). During chemotherapy with DXR and ifosfamide for high-grade soft tissue sarcoma, $90 \%$ of patients experienced nausea despite antiemetic prophylaxis therapy. Severe nausea was seen in $26.4 \%$ of patients during preoperative chemotherapy and in 16.9\% patients during postoperative chemotherapy (14). In a similar study, $85 \%$ of patients treated with prophylactic dexamethasone and $5-\mathrm{HT}_{3}$ receptor antagonists suffered from nausea, and 70\% of patients treated with dexamethasone, $5-\mathrm{HT}_{3}$ receptor antagonists, and NK1 receptor antagonists (aprepitant) suffered from nausea (11).

Undernutrition or malnutrition is a serious clinical condition that causes adverse effects on patient quality of life and survival $(15,16)$. During cancer treatment, undernutrition is a risk factor for infectious complications and treatment intolerance (17). Moreover, undernutrition in patients with cancer is an adverse prognostic factor (18). CINV may result in malnutrition $(19,20)$. Patients experiencing CINV are susceptible to malnutrition due to the direct effects of nausea and vomiting (4). It has been suggested that nutritional status in patients with CINV should be actively monitored and managed to reduce the risk of malnutrition (4). Moreover, measurement of food intake is a proposed tool for evaluating abdominal symptoms and determining the need for rescue agents (21). In this study, the incidence of CINV was evaluated in patients undergoing consecutive-day chemotherapy for bone and soft-tissue sarcomas who received appropriate antiemetic prophylaxis. Dietary energy intake was also analyzed. Associated factors were analyzed, including the anticancer agents themselves.

\section{MATERIALS AND METHODS}

\section{Study Design}

Patients diagnosed with bone and soft-tissue sarcomas and treated with consecutive-day chemotherapy from June 2012 to September 2013 at Kokura Medical Center were retrospectively reviewed. The incidence of CINV and the dietary energy intake were analyzed. All bone and soft-tissue tumors were stage III or IV, according to the American Joint Committee on Cancer stage classification. Antiemetic prophylaxis therapy was administered according to current guidelines (22-24). Patients receiving palliative chemotherapy were excluded. Patients younger than 15 years of age and older than 70 years of age were also excluded. The performance status of all patients was either 0 or 1 . Successful CINV control during days $0-5$ of chemotherapy was analyzed. Symptom control was defined as no emetic episodes and no use of rescue medications. Adverse events were defined by CTCAE ver. 4.0.

\section{Chemotherapy Regimens}

Chemotherapeutic regimens were as follows: DXR regimen (30 mg/m $\mathrm{m}^{2}$ DXR per day for 2 days), AI regimen $\left(30 \mathrm{mg} / \mathrm{m}^{2}\right.$ DXR per day for 2 days and $2 \mathrm{~g} / \mathrm{m}^{2}$ ifosfamide per day for 5 days), AP regimen $\left(30 \mathrm{mg} / \mathrm{m}^{2}\right.$ DXR per day for 2 days and $120 \mathrm{mg} / \mathrm{m}^{2}$ CDDP), VDC regimen ( $1.5 \mathrm{mg} / \mathrm{m}^{2}$ (maximum dosage: $2.0 \mathrm{mg}$ ) vincristine, $30 \mathrm{mg} / \mathrm{m}^{2}$ DXR per day for 2 days, and $1,200 \mathrm{mg} / \mathrm{m}^{2}$ cyclophosphamide), and IE regimen $\left(1.8 \mathrm{~g} / \mathrm{m}^{2}\right.$ ifosfamide per day for 5 days and $100 \mathrm{mg} / \mathrm{m}^{2}$ etoposide per day for 5 days). Each regimen was chosen according to the pathological diagnosis.

\section{Antiemetic Prophylaxis Therapy}

Antiemetic prophylaxis therapy was based on the emetogenic risk of each chemotherapy regimen $(3,6,25)$. The DXR and IE 
regimens were classified as moderate emetogenic risk. AI, AP, and VDC were classified as high emetogenic risk. A combination of $5-\mathrm{HT}_{3}$ receptor antagonists (Granisetron) and dexamethasone was used for DXR. Triple antiemetic prophylaxis including NK1 receptor antagonists (Aprepitant), 5- $\mathrm{HT}_{3}$ receptor antagonists, and dexamethasone was used for IE, AI, AP, and VDC. Though the IE regimen is a moderate emetogenic risk regimen, triple antiemetic prophylaxis was used for the regimen (1).

\section{Prevention of CINV}

Chemotherapy-induced nausea and vomiting prevention was defined as the absence of vomiting and the absence of rescue therapy for vomiting or nausea. Metoclopramide was used as rescue therapy.

\section{Calculation of Dietary Energy Intake}

The amount of oral energy intake was calculated based on information gathered from medical records, nursing records, and the hospital food ordering system. Energy requirements were calculated using the Harris-Benedict equation, a formula that uses the basal metabolic rate and applies an activity factor to determine total daily energy expenditure.

\section{Constipation and Hiccups}

The incidences of constipation and hiccups were evaluated based on information gathered from the medical and nursing records.

\section{Statistical Analysis}

Fisher's exact test was used to compare qualitative data including vomiting, chemotherapy regimens, hiccups, constipation, and patient background. The nonparametric Mann-Whitney $U$-test was used to compare quantitative data. The Kruskal-Wallis test was used, as appropriate, to compare dietary energy intake before starting chemotherapy and each day thereafter. A $P$-value less than 0.05 was considered statistically significant. All statistical analyses were performed using GraphPad Prism software, 5 for Windows Version 5.02 (GraphPad Software, Inc.).

\section{Institutional Review Board Statement}

This study was reviewed and approved by the Ethics Committee of National Hospital Organization, Kokura Medical Center, Kitakyushu City, Japan.

\section{Informed Consent Statement}

Patients were not required to give informed consent because the analysis used anonymous clinical data. On the home page of National Hospital Organization, Kokura Medical Center, all patients are alerted that anonymous data may be used for clinical studies.

\section{RESULTS}

\section{Patients}

A total of 13 patients were enrolled in the study. Demographic data are presented in Table 1. The patients included 10 males and 3 females. The mean age was $39.7 \pm 18.8$ years old, ranging from
17 to 69 years with a median of 35.5 years. The mean body weight was $39.7 \pm 18.8 \mathrm{~kg}$, ranging from 40.4 to $120 \mathrm{~kg}$ with a median of $35.5 \mathrm{~kg}$, and the mean body mass index was $27.2 \mathrm{~kg} / \mathrm{m}^{2}$ (range: 19.1-40.5). The histological diagnoses and cancer subtypes were as follows: bone tumors included two osteosarcomas, one Ewing sarcoma, and one undifferentiated pleomorphic sarcoma; soft-tissue tumors included two malignant peripheral nerve sheath tumors, two synovial sarcomas, two Ewing sarcomas, one rhabdomyosarcoma (pleomorphic type), one leiomyosarcoma, and one- liposarcoma (dedifferentiated). Metastatic disease was seen in 6 of the 13 patients, and 8 out of 16 chemotherapy courses.

\section{Chemotherapy and Antiemetic Prophylaxis Therapy}

A total of 16 chemotherapy courses were reviewed. DXR chemotherapy was administered to six patients, AI chemotherapy was administered to three patients, AP chemotherapy was administered to two patients, VDC chemotherapy was administered to two patients, and IE chemotherapy was administered to three patients (Table 2). Patients receiving DXR therapy, a moderate emetogenic risk regimen, also received $3 \mathrm{mg} 5-\mathrm{HT}_{3}$ receptor antagonists as a single fixed intravenous dose that was administered $30 \mathrm{~min}$ before chemotherapy, and $6.6 \mathrm{mg}$ dexamethasone. Patients receiving AI, AP, and VDC, high emetogenic risk regimens, and IE, a moderate emetogenic risk regimen, also received $3 \mathrm{mg} 5-\mathrm{HT} 3$ receptor antagonists and $6.6 \mathrm{mg}$ dexamethasone as a single fixed intravenous dose that was administered $30 \mathrm{~min}$ before chemotherapy. Patients subsequently received $3 \mathrm{mg} 5-\mathrm{HT}_{3}$ receptor antagonists twice daily on

\begin{tabular}{|c|c|c|}
\hline \multirow[t]{2}{*}{ Gender (n) } & Male & 10 \\
\hline & Female & 3 \\
\hline \multirow[t]{2}{*}{ Age (years) } & Mean & $39.7 \pm 18.8$ \\
\hline & Range & $17-69$ \\
\hline \multirow[t]{2}{*}{ Body mass index (BMI) } & Mean & $39.7 \pm 18.8$ \\
\hline & Range & \\
\hline \multirow[t]{2}{*}{ Metastatic status } & + & 6 \\
\hline & - & 7 \\
\hline \multirow[t]{2}{*}{ History of chemotherapy } & First line & 13 \\
\hline & Second line & 0 \\
\hline \multirow{4}{*}{$\begin{array}{l}\text { Previous number of } \\
\text { chemotherapy courses }\end{array}$} & Average & $1.25(0-7)$ \\
\hline & 0 & $n=10$ \\
\hline & 1 & $n=3$ \\
\hline & $3-5$ & $n=3$ \\
\hline \multirow[t]{3}{*}{ Bone tumors $(n=4)$} & Osteosarcoma & 2 \\
\hline & Ewing sarcoma & 1 \\
\hline & Undifferentiated pleomorphic sarcoma & 1 \\
\hline \multirow[t]{6}{*}{ Soft-tissue tumors $(n=9)$} & $\begin{array}{l}\text { Malignant peripheral nerve sheath } \\
\text { tumor (MPNST) }\end{array}$ & 2 \\
\hline & Synovial sarcoma & 2 \\
\hline & Ewing sarcoma & 2 \\
\hline & $\begin{array}{l}\text { Rhabdomyosarcoma, pleomorphic } \\
\text { type }\end{array}$ & 1 \\
\hline & Leiomyosarcoma & 1 \\
\hline & Liposarcoma, dedifferentiated & 1 \\
\hline \multirow[t]{2}{*}{ Metastasis } & Positive & \\
\hline & Negative & \\
\hline
\end{tabular}


days $1-4$, and once daily on day 5 . All patients received $125 \mathrm{mg}$ NK1 receptor antagonists orally on the first day, and $80 \mathrm{mg} /$ day thereafter. All 16 patients received first-line chemotherapy. The average number of previous chemotherapy courses was $1.25 ; 10$ patients had received no prior chemotherapy, 3 patients had one prior course of chemotherapy, and 3 patients had three to five prior chemotherapy courses.

\section{Frequency of CINV}

Vomiting occurred during four chemotherapy courses, in four different patients. All four chemotherapy courses included DXR. Furthermore, two contained cisplatin (AP regimen), one contained ifosfamide (AI regime), and one contained singleagent DXR. One vomiting episode was grade 3 (in a cisplatincontaining regimen), and the others were grade 1 . Nausea was reported in the same four patients. One nausea episode was grade

TABLE 2 | Chemotherapy regimens for bone and soft-tissue sarcoma.

\begin{tabular}{|c|c|c|c|c|c|}
\hline Regimens & Agents & Amounts & Day & Emetic risk & Antiemetics \\
\hline $\operatorname{DXR}(n=6)$ & DXR & $30 n$ & Days 1-2 & Moderate & $\begin{array}{l}\text { Granisetron } \\
\text { Dexamethasone }\end{array}$ \\
\hline $\mathrm{Al}(n=3)$ & $\begin{array}{l}\text { DXR } \\
\text { IFO }\end{array}$ & $\begin{array}{l}30 \mathrm{mg} / \mathrm{m}^{2} \\
2 \mathrm{~g} / \mathrm{m}^{2}\end{array}$ & $\begin{array}{l}\text { Days } 1-2 \\
\text { Days } 1-5\end{array}$ & High & $\begin{array}{l}\text { Granisetron } \\
\text { Dexamethasone } \\
\text { Aprepitant }\end{array}$ \\
\hline $\operatorname{AP}(n=2)$ & $\begin{array}{l}\text { DXR } \\
\text { CDDP }\end{array}$ & $\begin{array}{l}30 \mathrm{mg} / \mathrm{m}^{2} \\
120 \mathrm{mg} / \mathrm{m}^{2}\end{array}$ & $\begin{array}{l}\text { Days 1-2 } \\
\text { Day } 1\end{array}$ & High & $\begin{array}{l}\text { Granisetron } \\
\text { Dexamethasone } \\
\text { Aprepitant }\end{array}$ \\
\hline $\operatorname{VDC}(n=2)$ & $\begin{array}{l}\text { VCR } \\
\text { DXR } \\
\text { CPA }\end{array}$ & $\begin{array}{l}1.5 \mathrm{mg} / \mathrm{m}^{2} \\
37.5 \mathrm{mg} / \mathrm{m}^{2} \\
1,200 \mathrm{mg} / \mathrm{m}^{2}\end{array}$ & $\begin{array}{l}\text { Day } 1 \\
\text { Days 1-2 } \\
\text { Day } 1\end{array}$ & High & $\begin{array}{l}\text { Granisetron } \\
\text { Dexamethasone } \\
\text { Aprepitant }\end{array}$ \\
\hline $\mathrm{IE}(n=3)$ & $\begin{array}{l}\text { IFO } \\
\text { VP-16 }\end{array}$ & $\begin{array}{l}1.8 \mathrm{~g} / \mathrm{m}^{2} \\
100 \mathrm{mg} / \mathrm{m}^{2}\end{array}$ & $\begin{array}{l}\text { Days } 1-5 \\
\text { Days } 1-5\end{array}$ & Moderate & $\begin{array}{l}\text { Granisetron } \\
\text { Dexamethasone } \\
\text { Aprepitant }\end{array}$ \\
\hline
\end{tabular}

Al, doxorubicin and ifosfamide; $A P$, doxorubicin and cisplatin; CDDP, cisplatin; CPA, cyclophosphamide; DXR, doxorubicin; IE, fosfamide and etoposide; IFO, ifosfamide; VCR, vincristine; VDC, vincristine, doxorubicin and cyclophosphamide; VP-16, etoposide.
3 (in a cisplatin-containing regimen), and the others were grade 2. Consequently, the successful prevention of CINV at day 1 was $93.8 \%$. The successful prevention of CINV on days 2-5 was $81.3,81.3,75.0$, and $75.0 \%$, respectively. There was a tendency for CINV control rate to decrease over the course of treatment (Figure 1). No statistically significant correlations were observed between the occurrence of vomiting and patient gender or age, metastatic status, the emetic risk of treatment regimens, or history of chemotherapy (Table 3 ).

\section{Dietary Energy Intake}

Dietary energy intake during days $0-6$ of chemotherapy is shown in Figure 1. The average dietary energy intake on the day before chemotherapy initiation (day 0) was $77.9 \%$ of the expected caloric intake. Intake gradually decreased to $43.8 \%$ on day 3 , $38.1 \%$ on day 4 , and $47.9 \%$ on day 5 . Decreased energy intake was associated with the occurrence of CINV $(P<0.05)$. Dietary energy intake was significantly lower on day 4 , compared to day 0 . Anorexia grades were less than 2, except in one patient with grade 3 anorexia (the same patient who experienced vomiting during a cisplatin-containing regimen).

\section{Incidences of Hiccups and Constipation}

Figure 2 shows the occurrences of constipation and hiccups during the chemotherapy courses. Hiccups occurred in 3 of the 16 chemotherapy courses. Hiccups were treated with hydroxyzine. The rate of hiccups on chemotherapy day 1 was $0 \%$, whereas the rate on day 5 was $18.8 \%$. The incidence of hiccups was not associated with demographic patient data, metastatic state, history of chemotherapy or cisplatin-containing regimens. Constipation occurred in 7 of the 16 chemotherapy courses. Constipation was treated with magnesium oxide, sennosides, or bisacodyl. Constipation tended to occur more frequently on days 3-5 than on days 1 and 2. The occurrence rate of constipation on chemotherapy day 1 was $25.0 \%$, whereas the occurrence rate on day 5 was $37.5 \%$. Constipation was significantly associated with older patient age; the mean age of patients with constipation was
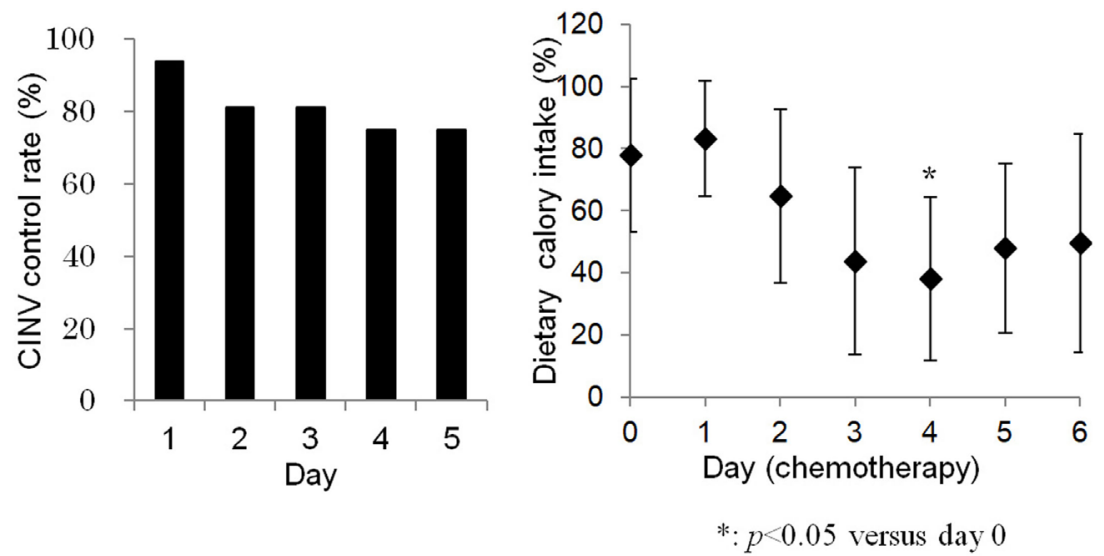

FIGURE 1 | Chemotherapy-induced nausea and vomiting control gradually decreased during consecutive-day regimens (left). Dietary calory intake was significantly lower at day 4 compared to day 0 (right). 
TABLE 3 | Correlations between patient characteristics and the occurrence of vomiting, hiccups, and constipation.

\begin{tabular}{|c|c|c|c|c|c|c|c|}
\hline & & Vomit $(n=4)$ & No vomit $(n=12)$ & Hiccup $(n=3)$ & No hiccup ( $n=13$ ) & Const $(n=7)$ & No const $(n=9)$ \\
\hline \multirow[t]{2}{*}{ Age (years) } & Mean & 27.3 & 43.8 & 41.0 & 39.4 & $51.6^{\mathrm{a}}$ & 30.4 \\
\hline & & \multicolumn{2}{|c|}{$\mathrm{NS}(P=0.16)$} & \multicolumn{2}{|c|}{$\mathrm{NS}(P=0.69)$} & \multicolumn{2}{|c|}{$P=0.026$} \\
\hline \multirow[t]{3}{*}{ Gender } & Male & 4 & 8 & 3 & 9 & 4 & 8 \\
\hline & Female & 0 & 4 & 0 & 4 & 3 & 1 \\
\hline & & \multicolumn{2}{|c|}{$\mathrm{NS}(P=0.52)$} & \multicolumn{2}{|c|}{$\mathrm{NS}(P=0.53)$} & \multicolumn{2}{|c|}{$\mathrm{NS}(P=0.26)$} \\
\hline \multirow[t]{3}{*}{ Metastatic state } & + & 1 & 7 & 2 & 6 & 3 & 5 \\
\hline & - & 3 & 5 & 1 & 7 & 4 & 4 \\
\hline & & \multicolumn{2}{|c|}{$\mathrm{NS}(P=0.569)$} & \multicolumn{2}{|c|}{$\mathrm{NS}(P=1)$} & \multicolumn{2}{|c|}{$\mathrm{NS}(P=1)$} \\
\hline \multirow[t]{3}{*}{ Emetic risk } & High & 3 & 4 & 2 & 5 & 2 & 5 \\
\hline & Mod & 1 & 8 & 1 & 8 & 5 & 4 \\
\hline & & \multicolumn{2}{|c|}{$\mathrm{NS}(P=0.26)$} & \multicolumn{2}{|c|}{$\mathrm{NS}(P=0.55)$} & \multicolumn{2}{|c|}{$\mathrm{NS}(P=0.36)$} \\
\hline \multirow[t]{3}{*}{ History of chemo } & + & 1 & 5 & 0 & 6 & 2 & 4 \\
\hline & - & 3 & 7 & 3 & 7 & 5 & 5 \\
\hline & & \multicolumn{2}{|c|}{$\mathrm{NS}(P=1)$} & \multicolumn{2}{|c|}{$\mathrm{NS}(P=0.25)$} & \multicolumn{2}{|c|}{$\mathrm{NS}(P=0.633)$} \\
\hline \multirow[t]{3}{*}{ Cisplatin $^{b}$} & + & 2 & 0 & 1 & 1 & 0 & 2 \\
\hline & - & 2 & 12 & 2 & 12 & 7 & 7 \\
\hline & & \multicolumn{2}{|c|}{$\mathrm{NS}(P=0.05)$} & \multicolumn{2}{|c|}{$\mathrm{NS}(P=0.35)$} & \multicolumn{2}{|c|}{$\mathrm{NS}(P=0.48)$} \\
\hline
\end{tabular}

Chemo, chemotherapy; Const, constipation; F, female; $M$, male; mod, moderate; NS, not significant.

${ }^{a} P<0.05$.

${ }^{b}$ Cisplatin, cisplatin-containing regimen.
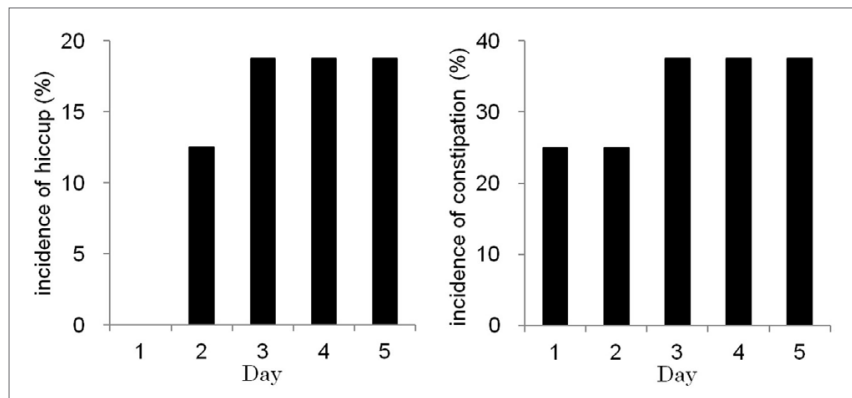

FIGURE 2 | The incidences of hiccups (left) and constipation (right) were high on days 3-5 during consecutive-day chemotherapy.

51.6 years old, and the mean age of patients without constipation was 29.1 years old $(P<0.05)$ (Table 3$)$.

\section{DISCUSSION}

The degree of CINV is based on CINV frequency and depends on the type and dose of anticancer agents. High emetogenic risk agents cause CINV in more than $90 \%$ of patients, moderate emetogenic risk agents cause CINV in $30-90 \%$ of patients, and low emetogenic risk agents cause CINV in less than $30 \%$ of patients (1). Consecutive-day regimens with multiple chemotherapy agents are commonly used to treat bone and soft-tissue sarcomas. In the current study, all chemotherapy regimens were either moderate or high emetogenic risk. Despite appropriate antiemetic prophylaxis therapy, successful prevention of CINV decreased from day 1 to day 5 of chemotherapy, and 4 out of 13 patients experienced vomiting. We observed no differences in CINV between patients with or without a prior history of chemotherapy. In a previous report of chemotherapy using DXR plus ifosfamide for soft tissue sarcomas, the incidence of severe nausea seemed to be lower in patients receiving postoperative chemotherapy (16.9\%) than in those receiving preoperative chemotherapy (26.4\%) (14). For patients receiving multicourse chemotherapy, early CINV control is important, because a history of poorly controlled CINV is a risk factor for future CINV $(4,26)$.

Evidence-based guidelines provide limited options for antiemetic therapy to prevent CINV in patients undergoing consecutive-day chemotherapy (27). It is unclear which antiemetic agents should be administered for consecutive-day regimens (1). Palonosetron has a longer half-life and greater $5-\mathrm{HT}_{3}$ receptor binding affinity compared to other $5-\mathrm{HT}_{3}$ receptor antagonists (28). Randomized controlled trials have shown that palonosetron leads to better control of delayed emesis and delayed nausea compared to other $5-\mathrm{HT}_{3}$ receptor antagonists (29-32). However, consecutive-day granisetron was shown to be non-inferior to single-shot palonosetron for treating CINV in patients with bone and soft tissue sarcoma (1).

The risk of CINV is, in part, determined by the emetogenic potential of the chemotherapy regimen (4). CINV appears to be associated with cisplatin-containing chemotherapy regimens. The AP regimen (DXR plus cisplatin) is a combination of $120 \mathrm{mg} / \mathrm{m}^{2}$ cisplatin and $60 \mathrm{mg} / \mathrm{m}^{2} \mathrm{DXR}$, and is frequently used to treat sarcomas such as osteosarcoma. This regimen is classified as high emetic risk. The dosage of cisplatin is rather high compared to treatment regimens for other types of cancer (33). The AP regimen should be considered an extremely high emetic risk regimen (1). The chemotherapy regimens administered for bone and soft tissue sarcomas may require stronger antiemetic therapies. Metoclopramide has been shown to be effective for protracted nausea and vomiting during chemotherapy with advanced emetogenic risk agents (34). Another report suggested that the addition of olanzapine may be effective in CINV that is not controlled with triple antiemetic prophylaxis $(35,36)$. 
Various chemotherapy-related symptoms can influence nutrition, including nausea, appetite loss, lack of energy, and taste changes (37). CINV are considered symptoms that influence nutrition and that can result in malnutrition $(20,38$, 39). Malnutrition causes impairments of the immune system, performance status, muscle function, and quality of life (40). Moreover, cancerinduced malnutrition is associated with a decreased response to chemotherapy, more frequent complications, and severe toxicity (18). Malnutrition is also considered an independent risk factor for mortality $(41,42)$. Dietary interventions may help in the management of CINV (4). It has been suggested that patients with cancer should undergo nutritional counseling at the time of diagnosis and should be monitored throughout treatment (40). In the present study, dietary energy intake was assessed. No patient had severe anorexia. However, dietary energy intake decreased on day 4 of chemotherapy administration, which was related to the occurrence of CINV. One patient receiving a cisplatin-containing regimen had grade 3 anorexia. Antiemetic prophylaxis with triplet antiemetic combination therapy was not sufficient to control CINV or maintain dietary energy intake during chemotherapy for bone and soft tissue sarcoma.

The occurrences of hiccups and constipation were also analyzed in this study. Hiccups tended to occur more often on days 3-5 than on days 1 and 2. Cisplatin, dexamethasone, and NK1 receptor antagonists are known to cause hiccups (33). However, in our series, the incidence of hiccups was not associated with patient demographics or cisplatin-containing regimens. Constipation tended to occur more often on days 3-5 than on days 1 and 2 . Elderly age was the only risk factor for constipation, consistent with a previous report (43). Anticancer agents like cisplatin and DXR cause diarrhea (44). On the other hand, 5- $\mathrm{HT}_{3}$ receptor antagonists can cause constipation (43). Therefore, the administration of $5-\mathrm{HT}_{3}$ receptor antagonists during consecutive-day chemotherapy may have caused constipation in the current study. The exact features contributing to hiccups and constipation are unknown. However, the frequency of hiccups and constipation increased during consecutive-day chemotherapy, especially in elderly patients.

\section{REFERENCES}

1. Kimura H, Yamamoto N, Shirai T, Nishida H, Hayashi K, Tanzawa Y, et al. Efficacy of triplet regimen antiemetic therapy for chemotherapy-induced nausea and vomiting (CINV) in bone and soft tissue sarcoma patients receiving highly emetogenic chemotherapy, and an efficacy comparison of single-shot palonosetron and consecutive-day granisetron for CINV in a randomized, single-blinded crossover study. Cancer Med (2015) 4:333-41.

2. Hesketh PJ. Chemotherapy-induced nausea and vomiting. $N$ Engl J Med (2008) 358:2482-94. doi:10.1056/NEJMra0706547

3. Herrstedt J. Antiemetics: an update and the MASCC guidelines applied in clinical practice. Nat Clin Pract Oncol (2008) 5:32-43. doi:10.1038/ncponc1021

4. Marx W, Kiss N, McCarthy AL, McKavanagh D, Isenring L. Chemotherapyinduced nausea and vomiting: a narrative review to inform dietetics practice. J Acad Nutr Diet (2016) 116:819-27. doi:10.1016/j.jand.2015.10.020

5. Olver IN, Eliott JA, Koczwara B. A qualitative study investigating chemotherapy-induced nausea as a symptom cluster. Support Care Cancer (2014) 22:2749-56. doi:10.1007/s00520-014-2276-2

6. Kris MG, Hesketh PJ, Somerfield MR, Feyer P, Clark-Snow R, Koeller JM, et al. American Society of Clinical Oncology guideline for antiemetics in oncology: update 2006. J Clin Oncol (2006) 24:2932-47. doi:10.1200/JCO. 2006.06.9591
This study has several limitations. First, this is a retrospective study. Second, the number of cases is small, due to the rare nature of bone and soft-tissue tumors. Third, patients were observed for less than one week. The limited number of cases and the limited time course of this study cannot support a definitive conclusion. However, observing nutritional status, which may reflect general patient condition, may be important during consecutive-day chemotherapy for rare bone and soft-tissue sarcomas.

\section{CONCLUSION}

Chemotherapy for bone and soft tissue tumors generally includes high doses of anticancer medications and consecutive-day regimens. We found that the incidences of hiccups and constipation increased during the course of consecutive-day chemotherapy. Furthermore, antiemetic prophylaxis therapy using a triple drug combination was not sufficient to control CINV, especially in patients receiving cisplatin-containing regimens. CINV was associated with decreased dietary energy intake during chemotherapy. Nutritional counseling may be helpful in supporting nutritional status during chemotherapy.

\section{ETHICS STATEMENT}

This study was reviewed and approved by the Ethics Committee of National Hospital Organization, Kokura Medical Center, Kitakyushu city, Japan, where the research was performed.

\section{AUTHOR CONTRIBUTIONS}

YH, AS, TG, MS, and TU designed the study; YH, TG, SA, and MY performed the data collection and sample analysis; $\mathrm{YH}$ and TG analyzed the data; YH and AS wrote the article. AS had primary responsibility for the final content. All authors read, critically revised, and approved the final manuscript.

7. Jordan K, Sippel C, Schmoll HJ. Guidelines for antiemetic treatment of chemotherapy-induced nausea and vomiting: past, present, and future recommendations. Oncologist (2007) 12:1143-50. doi:10.1634/ theoncologist.12-9-1143

8. Basch E, Prestrud AA, Hesketh PJ, Kris MG, Feyer PC, Somerfield MR, et al. Antiemetics: American Society of Clinical Oncology clinical practice guideline update. J Clin Oncol (2011) 29:4189-98. doi:10.1200/ JCO.2010.34.4614

9. Horn CC. Why is the neurobiology of nausea and vomiting so important? Appetite (2008) 50:430-4. doi:10.1016/j.appet.2007.09.015

10. National Comprehensive Cancer Network. NCCN Clinical Practice Guidelines in Oncology (NCCN Guidelines ${ }^{\circledR}$ ): Antiemesis. Version 1. Fort Washington, PA: National Comprehensive Cancer Network (2014).

11. Kusaba H, Kumagai H, Inadomi K, Matsunobu T, Harimaya K, Takayoshi K, et al. Efficacy analysis of the aprepitant-combined antiemetic prophylaxis for non-round cell soft-tissue sarcoma patients received adriamycin and ifosfamide therapy. Medicine (Baltimore) (2016) 95:e5460. doi:10.1097/ MD.0000000000005460

12. Colosia A, Khan S, Hackshaw MD, Oglesby A, Kaye JA, Skolnik JM. A systematic literature review of adverse events associated with systemic treatments used in advanced soft tissue sarcoma. Sarcoma (2016) 2016:1-13. doi:10.1155/2016/3597609 
13. Lee AT, Pollack SM, Huang P, Jones RL. Phase III soft tissue sarcoma trials: success or failure? Curr Treat Options Oncol (2017) 18:19. doi:10.1007/ s11864-017-0457-1

14. Tanaka K, Mizusawa J, Fukuda H, Araki N, Chuman H, Takahashi M, et al. Perioperative chemotherapy with ifosfamide and doxorubicin for high-grade soft tissue sarcomas in the extremities (JCOG0304). Jpn J Clin Oncol (2015) 45:555-61. doi:10.1093/jjco/hyv042

15. Deluche E, Girault S, Jesus P, Monzat S, Turlure P, Leobon S, et al. Assessment of the nutritional status of adult patients with acute myeloid leukemia during induction chemotherapy. Nutrition (2017) 41:120-5. doi:10.1016/j. nut.2017.04.011

16. Qiu M, Zhou YX, Jin Y, Wang ZX, Wei XL, Han HY, et al. Nutrition support can bring survival benefit to high nutrition risk gastric cancer patients who received chemotherapy. Support Care Cancer (2015) 23:1933-9. doi:10.1007/ s00520-014-2523-6

17. Schneider SM, Veyres P, Pivot X, Soummer AM, Jambou P, Filippi J, et al. Malnutrition is an independent factor associated with nosocomial infections. Br J Nutr (2004) 92:105-11. doi:10.1079/BJN20041152

18. Van Cutsem E, Arends J. The causes and consequences of cancer-associated malnutrition. Eur J Oncol Nurs (2005) 9:S51-63. doi:10.1016/j. ejon.2005.09.007

19. Farrell C, Brearley SG, Pilling M, Molassiotis A. The impact of chemotherapy-related nausea on patients' nutritional status, psychological distress and quality of life. Support Care Cancer (2013) 21:59-66. doi:10.1007/ s00520-012-1493-9

20. Thoresen L, Fjeldstad I, Krogstad K, Kaasa S, Falkmer UG. Nutritional status of patients with advanced cancer: the value of using the subjective global assessment of nutritional status as a screening tool. Palliat Med (2002) 16:33-42. doi:10.1191/0269216302pm486oa

21. Tamura K, Aiba K, Saeki T, Nakanishi Y, Kamura T, Baba H, et al. Breakthrough chemotherapy-induced nausea and vomiting: report of a nationwide survey by the CINV Study Group of Japan. Int J Clin Oncol (2017) 22:405-12. doi:10.1007/s10147-016-1069-7

22. Bloechl-Daum B, Deuson RR, Mavros P, Hansen M, Herrstedt J. Delayed nausea and vomiting continue to reduce patients' quality of life after highly and moderately emetogenic chemotherapy despite antiemetic treatment. J Clin Oncol (2006) 24:4472-8. doi:10.1200/JCO.2006.05.6382

23. Herrstedt J, Aapro MS, Roila F, Kataja VV; ESMO Guidelines Task Force. ESMO minimum clinical recommendations for prophylaxis of chemotherapy-induced nausea and vomiting (NV). Ann Oncol (2005) 16(Suppl 1):i77-9. doi:10.1093/annonc/mdi805

24. Gralla RJ, Osoba D, Kris MG, Kirkbride P, Hesketh PJ, Chinnery LW, et al. Recommendations for the use of antiemetics: evidence-based, clinical practice guidelines. American Society of Clinical Oncology. J Clin Oncol (1999) 17:2971-94. doi:10.1200/JCO.1999.17.9.2971

25. Roila F, Herrstedt J, Aapro M, Gralla RJ, Einhorn LH, Ballatori E, et al. Guideline update for MASCC and ESMO in the prevention of chemotherapy- and radiotherapy-induced nausea and vomiting: results of the Perugia consensus conference. Ann Oncol (2010) 21(Suppl 5):v232-43. doi:10.1093/ annonc/mdq194

26. Persistence of efficacy of three antiemetic regimens and prognostic factors in patients undergoing moderately emetogenic chemotherapy. Italian Group for Antiemetic Research. JClin Oncol (1995) 13:2417-26. doi:10.1200/ JCO.1995.13.9.2417

27. Affronti ML, Bubalo J. Palonosetron in the management of chemotherapy-induced nausea and vomiting in patients receiving multiple-day chemotherapy. Cancer Manag Res (2014) 6:329-37. doi:10.2147/CMAR.S68102

28. Navari RM. Palonosetron: a second generation 5-hydroxytryptamine 3 receptor antagonist. Expert Opin Drug Metab Toxicol (2009) 5:1577-86. doi:10.1517/17425250903407289

29. Botrel TE, Clark OA, Clark L, Paladini L, Faleiros E, Pegoretti B. Efficacy of palonosetron (PAL) compared to other serotonin inhibitors (5-HT3R) in preventing chemotherapy-induced nausea and vomiting (CINV) in patients receiving moderately or highly emetogenic (MoHE) treatment: systematic review and meta-analysis. Support Care Cancer (2011) 19:823-32. doi:10.1007/ s00520-010-0908-8

30. Schwartzberg L, Barbour SY, Morrow GR, Ballinari G, Thorn MD, Cox D. Pooled analysis of phase III clinical studies of palonosetron versus ondansetron, dolasetron, and granisetron in the prevention of chemotherapy-induced nausea and vomiting (CINV). Support Care Cancer (2014) 22:469-77. doi:10.1007/s00520-013-1999-9

31. Jin Y, Sun W, Gu D, Yang J, Xu Z, Chen J. Comparative efficacy and safety of palonosetron with the first 5-HT3 receptor antagonists for the chemotherapy-induced nausea and vomiting: a meta-analysis. Eur J Cancer Care (Engl) (2013) 22:41-50. doi:10.1111/j.1365-2354.2012.01353.x

32. Likun Z, Xiang J, Yi B, Xin D, Tao ZL. A systematic review and meta-analysis of intravenous palonosetron in the prevention of chemotherapy-induced nausea and vomiting in adults. Oncologist (2011) 16:207-16. doi:10.1634/ theoncologist.2010-0198

33. Albany C, Brames MJ, Fausel C, Johnson CS, Picus J, Einhorn LH. Randomized, double-blind, placebo-controlled, phase III cross-over study evaluating the oral neurokinin-1 antagonist aprepitant in combination with a 5HT3 receptor antagonist and dexamethasone in patients with germ cell tumors receiving 5-day cisplatin combination chemotherapy regimens: a Hoosier Oncology Group Study. J Clin Oncol (2012) 30:3998-4003. doi:10.1200/ JCO.2011.39.5558

34. Navari RM, Nagy CK, Gray SE. The use of olanzapine versus metoclopramide for the treatment of breakthrough chemotherapy-induced nausea and vomiting in patients receiving highly emetogenic chemotherapy. Support Care Cancer (2013) 21:1655-63. doi:10.1007/s00520-012-1710-6

35. Mizukami N, Yamauchi M, Koike K, Watanabe A, Ichihara K, Masumori N, et al. Olanzapine for the prevention of chemotherapy-induced nausea and vomiting in patients receiving highly or moderately emetogenic chemotherapy: a randomized, double-blind, placebo-controlled study. J Pain Symptom Manage (2014) 47:542-50. doi:10.1016/j.jpainsymman.2013.05.003

36. Vig S, Seibert L, Green MR. Olanzapine is effective for refractory chemotherapy-induced nausea and vomiting irrespective of chemotherapy emetogenicity. J Cancer Res Clin Oncol (2014) 140:77-82. doi:10.1007/s00432-013-1540-Z

37. Molassiotis A, Farrell C, Bourne K, Brearley SG, Pilling M. An exploratory study to clarify the cluster of symptoms predictive of chemotherapy-related nausea using random forest modeling. J Pain Symptom Manage (2012) 44:692-703. doi:10.1016/j.jpainsymman.2011.11.003

38. Isenring E, Cross G, Daniels L, Kellett E, Koczwara B. Validity of the malnutrition screening tool as an effective predictor of nutritional risk in oncology outpatients receiving chemotherapy. Support Care Cancer (2006) 14:1152-6. doi:10.1007/s00520-006-0070-5

39. Tong H, Isenring E, Yates P. The prevalence of nutrition impact symptoms and their relationship to quality of life and clinical outcomes in medical oncology patients. Support Care Cancer (2009) 17:83-90. doi:10.1007/s00520-008-0472-7

40. Viggiani MT, Lorusso O, Natalizio F, Principi M, Di Leo A, Barone M. Influence of chemotherapy on total energy expenditure in patients with gastrointestinal cancer: a pilot study. Nutrition (2017) 42:7-11. doi:10.1016/j.nut.2017.05.001

41. Pressoir M, Desné S, Berchery D, Rossignol G, Poiree B, Meslier M, et al. Prevalence, risk factors and clinical implications of malnutrition in French Comprehensive Cancer Centres. Br J Cancer (2010) 102:966-71. doi:10.1038/ sj.bjc. 6605578

42. Pirlich M, Schütz T, Norman K, Gastell S, Lübke HJ, Bischoff SC, et al. The German hospital malnutrition study. Clin Nutr (2006) 25:563-72. doi:10.1016/j.clnu.2006.03.005

43. Larkin PJ, Sykes NP, Centeno C, Ellershaw JE, Elsner F, Eugene B, et al. The management of constipation in palliative care: clinical practice recommendations. Palliat Med (2008) 22:796-807. doi:10.1177/0269216308096908

44. Richardson G, Dobish R. Chemotherapy induced diarrhea. J Oncol Pharm Pract (2007) 13:181-98. doi:10.1177/1078155207077335

Conflict of Interest Statement: The authors declare that the research was conducted in the absence of any commercial or financial relationships that could be construed as a potential conflict of interest.

The reviewers YL, RN, and the handling editor declared their shared affiliation.

Copyright ( 2018 Hori, Sakamoto, Goto, Ando, Yamashita, Shimomura and Uemura. This is an open-access article distributed under the terms of the Creative Commons Attribution License (CC BY). The use, distribution or reproduction in other forums is permitted, provided the original author(s) or licensor are credited and that the original publication in this journal is cited, in accordance with accepted academic practice. No use, distribution or reproduction is permitted which does not comply with these terms. 